\title{
Influence of emission size distribution and nucleation on number concentrations over Greater Paris
}

\author{
Karine Sartelet ${ }^{1}$, Youngseob Kim ${ }^{1}$, Florian Couvidat ${ }^{2}$, Maik Merkel ${ }^{3}$, Tuukka Petäjä ${ }^{4}$, Jean Sciare ${ }^{5}$, and \\ Alfred Wiedensohler ${ }^{3}$ \\ ${ }^{1}$ CEREA, École des Ponts ParisTech, EdF R\&D, IPSL, 77455 Marne la Vallée, France \\ ${ }^{2}$ INERIS, 60550 Verneuil en Halatte, France \\ ${ }^{3}$ Leibniz Institute for Tropospheric Research, Leipzig, Germany \\ ${ }^{4}$ Institute for Atmospheric and Earth System Research/Physics, University of Helsinki, 00014, Finland \\ ${ }^{5}$ Laboratoire des Sciences du Climat et de l'Environnement, Gif-sur-Yvette, France
}

Correspondence to: Karine Sartelet (karine.sartelet@enpc.fr)

\begin{abstract}
With the growing evidence that high particle number concentrations may impact health, modelling their emissions and understanding formation processes is necessary, especially in cities where many people are exposed. As emission inventories of particle numbers and size distribution over cities are usually not available, a methodology is defined to estimate them from $\mathrm{PM}_{2.5}$ emissions, ratios $\mathrm{PM}_{1} / \mathrm{PM}_{2.5}$ and $\mathrm{PM}_{0.1} / \mathrm{PM}_{2.5}$ by activity sector. In this methodology, a fitting parameter is used to redistribute the number concentrations in the lowest emission diameter range. This parameter is chosen by comparing measured and simulated number concentrations during non-nucleation days. The emission size distribution is then finely discretised by conserving both mass and number in each of the size ranges where emissions are specified. The methodology is applied over Greater Paris during the MEGAPOLI campaign (July 2009). Three-dimensional simulations are performed using the chemistry-transport model Polair3D/Polyphemus coupled to the aerosol module SSH-aerosol to represent the evolution of particles by condensation/evaporation, coagulation and nucleation, with a sectional approach for the size distribution. The model is first compared to measurements during non-nucleation days, and the influence over the month of July 2009 of three different nucleation parameterisations is assessed: a binary (sulfuric acid, water), ternary (sulfuric acid, ammonia, water) and heteromolecular (extremely-low volatile organic compounds (ELVOC) from monoterpenes and sulfuric acid). The modelled number concentrations compare very well to measurements with an average normalised mean error of $42 \%$ for the daily number concentrations of particles larger than $10 \mathrm{~nm}$, and $37 \%$ for the number concentrations of particles larger than $100 \mathrm{~nm}$. The influence of the binary nucleation is low, and the ternary nucleation scheme leads to better simulated number concentrations (in terms of bias and error) at only one site out of three, but it systematically reduces the model to measurement correlation, suggesting that ternary nucleation may not be the dominant process in new particle formation. However, the relative bias and error, as well as the correlation at suburban sites, are systematically improved using the heteromolecular nucleation scheme involving sulfuric acid and ELVOC from monoterpenes. This suggests that heteromolecular nucleation may be important in cities, especially at suburban sites in summer, and that a better characterisation of the emissions of ELVOC precursors from traffic is needed.
\end{abstract}




\section{Introduction}

Although ongoing air-quality regulations only apply to particle mass, the number of particles may also be a hazard to human health (Win-Shwe and Fujimaki, 2011; Kelly et al., 2011; Pascal et al., 2013; Downward et al., 2018; Rivas et al., 2021). For example, Oberdörster et al. (2005); Schraufnagel (2020) showed that particulate matter (PM) of diameters lower than $100 \mathrm{~nm}$ $\left(\mathrm{PM}_{0.1}\right.$, also called ultra-fine particles UFP) are responsible for pulmonary inflammation. Because of their small sizes, they can tranlocate to all organics (Schraufnagel, 2020). Because the mass of UFP is negligible, it contributes little to the total mass concentration of particles, but the number concentration of UFP is high. Because current regulations govern the mass of particles of aerodynamic diameters lower than or equal to $10 \mu \mathrm{m}\left(\mathrm{PM}_{10}\right)$ and $2.5 \mu \mathrm{m}\left(\mathrm{PM}_{2.5}\right)$, UFP are not regulated by those; and differences in maps of high mass and number concentrations have been reported (Ye et al., 2020).

Although most computational fluid dynamics and chemistry-transport models have focused until very recently to accurately represent the mass of particles, modelling the number of particles has become increasingly the subject of studies. At the local scale, the number of particles was modelled at the local exhaust outlet (Albriet et al., 2010; Xu et al., 2021), in the plumes of ships (Karl et al., 2020) and at the neighbouring scale (Karl et al., 2016; Kurppa et al., 2020; Ketzel et al., 2021; Kumar et al., 2022), stressing the large influence of nucleation and primary emissions from traffic. At the regional and global scale, chemistry-transport models with model to measurement comparisons of number concentrations were performed in the United States (Jung et al., 2010; Zhang et al., 2010a; Kelly et al., 2011) and more recently in Europe (Kukkonen et al., 2016; Fountoukis et al., 2012; Patoulias et al., 2018; Fanourgakis et al., 2019; Olin et al., 2021; Patoulias and Pandis, 2021; Frohn et al., 2021). Only a few studies performed simulations over cities (Kukkonen et al., 2016; Frohn et al., 2021), with poorer statistics than at the regional/global scale (Frohn et al., 2021).

The high number concentrations are largely due to UFP (de Jesus et al., 2019). In cities, the high particle number concentrations are thought to mostly originate from nucleation and traffic emissions in summer (Rivas et al., 2020; Casquero-Vera et al., 2022). These particles are difficult to represent because of uncertainties in their emission, in the nucleation process, but also because of difficulties to model their growth mechanisms (Yu et al., 2019). Indeed, many of the modelling studies listed previously represent the size distribution using a log-normal approach with 3 to 4 modes (Zhang et al., 2010a; Kelly et al., 2011; Kukkonen et al., 2016; Fanourgakis et al., 2019). However, such a coarse discretisation of low-diameter particles induces large uncertainties in number concentrations (Sartelet et al., 2006; Blichner et al., 2021). Furthermore, Blichner et al. (2021) found that the aerosol number concentrations are better modelled compared to observations if a sectional scheme is used for low-diameter particles.

The emissions of particle numbers are highly uncertain, and they are usually not reported in emission inventories, such as the European emission inventory (EMEP/EEA, 2019), or city inventories. In the framework of the EUCAARI project, a number emission inventory was built over Europe by size-segregating PM mass emission for the different sectors (Kulmala et al., 2011). Most of the regional-scale studies presented above used this emission inventory (Fountoukis et al., 2012; Patoulias et al., 2018; Patoulias and Pandis, 2021) or an updated version (Olin et al., 2021). Although the number concentrations may be particularly high in cities, number emissions are difficult to estimate. Kukkonen et al. (2016); Frohn et al. (2021) estimated number 
emissions from particle mass emissions for different anthropogenic sectors. These number emissions were then assigned to the Aitken mode of a modal size representation for 3D modelling. Such an approach is not appropriate for a sectional size representation where the aerosol dynamics is finely modelled. A methodology is needed to estimate particle number emissions and the size distribution at emissions for city-scale inventories.

Not only the primary emissions and size distribution at emission of UFP are highly uncertain, but also their formation from gas-phase precursors (nucleation) is still not well understood. Okuljar et al. (2021) showed that sub-3 nm particles may largely be directly emitted by traffic, but this contribution may be low during nucleation episodes. Nucleation is uncertain both in terms of the gas involved and their representation. Several parameterisations of binary nucleation (involving sulfuric acid and water) or ternary nucleation (involving sulfuric acid, ammonia and water) exist. Zhang et al. (2010b) compared binary and ternary nucleation parameterisations and found differences of several orders of magnitude among the parametrised nucleation rates. Among the parameterisations tested, those with a simple power law to describe the binary nucleation of sulfuric acid (Sihto et al., 2006; Kuang et al., 2008) compared best to observed nucleation rates. Zhang et al. (2010b) reported that the commonly-used binary parameterisations of Kulmala et al. (1998); Vehkamäki et al. (2002) or the ternary parameterisations of Napari et al. (2002); Merikanto et al. (2007), which are based on classical homogeneous nucleation models, over-estimate the nucleation rate. Organic vapors, such as highly oxygenated organic molecule (HOM) may also be involved in nucleation (Tröstl et al., 2016; Sulo et al., 2021). The large influence of the heteromolecular nucleation of sulfuric acid and organics has been underlined in a global modelling study (Zhu and Penner, 2019). However, the influence of heteromolecular nucleation was not assessed at the regional or city scale, where HOM are believed to mostly contribute to the growth of nano particles (Patoulias and Pandis, 2021).

This paper aims at modelling the number of particles over Greater Paris during summer, first by defining a methodology to estimate primary number emissions, and second by estimating nucleation parameterisations that best represent measurements. The simulations are performed during the summer MEGAPOLI campaign. The first section presents the model and the measurement data. The second section defines a methodology to estimate the number emissions from the different emission sectors. Finally, the fourth section studies the influence of nucleation (binary, ternary and heteromolecular with organics) on the number concentration.

\section{Presentation of the model and data}

\subsection{The model}

Simulations are performed with the 3-dimensional (3D) chemistry-transport model Polair3D (Sartelet et al., 2007) of the Polyphemus platform, which is coupled to the aerosol module SSH-aerosol (Sartelet et al., 2020). The gas-phase chemistry model is CB05, modified to represent the formation of semi-volatil organic compounds that may condense onto particles and form secondary organic aerosols (SOA) (Kim et al., 2011; Chrit et al., 2017). The considered SOA precursors are anthropogenic (toluene, xylenes, intermediate and semi-volatile organic compounds) and biogenic (monoterpenes, sesquiterpenes, isoprene). The myriad of SOA species formed during the oxidation of those precursors is modelled with surrogate organic molecules 
of representative physico-chemical properties (Couvidat et al., 2012; Sartelet et al., 2020). Some of the surrogates may be considered as non-volatile: the surrogate BiAD3 (3-methyl-1,2,3-butane tricarboxylic acid) from the monoterpene oxidation, the surrogates Monomer $\left(\mathrm{C}_{10} \mathrm{H}_{14} \mathrm{O}_{9}\right)$ and Dimer $\left(\mathrm{C}_{19} \mathrm{H}_{28} \mathrm{O}_{11}\right)$ from the monoterpene autoxidation, the surrogate AnClP from the xylenes and toluene low-NOx oxidation, the surrogate SOAIP (secondary organic aerosol of low volatility) from the oxidation of anthropogenic semi-volatile organic compounds. The growth of UFP is strongly impacted by the condensation of low-volatility compounds as well as coagulation. Therefore, numerically, the condensation of non-volatile compounds is solved dynamically with nucleation and coagulation processes, using the ETR (explicit trapezoidale rule) numerical scheme. In each section, particles grow because of condensation, leading to variations of the section diameters. Because the bound diameters of each section should remain fixed to ensure numerical consistency with coagulation and 3D transport, the number and mass concentrations are redistributed at each time step on the the fixed size (diameter) sections using the Euler-coupled approach (Devilliers et al., 2013). The condensation/evaporation of semi-volatile compounds is computed by assuming bulk thermodynamic equilibrium between the gas and the particle phases. The condensing matter estimated from bulk equilibrium is distributed over the aerosol size distribution by using weighting factors for each size section based on their condensation/evaporation kernel of the condensation/evaporation rate.

Different parameterisations of nucleations are implemented: the binary parameterisation of Kuang et al. (2008) involving sulfuric acid and water; the ternary parameterisation of Napari et al. (2002) involving sulfuric acid, water and ammonium; the heteromolecular parameterisation of Riccobono et al. (2014) involving sulfuric acid and oxidised biogenic compounds. The concentration of the oxidised biogenic compounds is assumed to be equal to the concentration of extremely-low volatile organic compounds (ELVOC) formed from the autoxidation of monoterpenes (Ehn et al., 2014; Chrit et al., 2017). Several studies rescaled the ternary parameterisation of Napari et al. (2002) using scaling factors of the order of $10^{-5}-10^{-6}$, because of too high nucleation rates (Fountoukis et al., 2012; Patoulias et al., 2018). A scaling factor of 0.001 is used here. As the heteromolecular parameterisation of Riccobono et al. (2014) also led to too high number concentrations, it is rescaled by a factor 0.1 .

The simulation domain (see Figure 4) and the model input data (meteorology and boundary conditions) are the same as in Royer et al. (2011); Couvidat et al. (2013). Only 5 size sections between $0.01 \mu \mathrm{m}$ and $10 \mu \mathrm{m}$ were used in these studies. To represent the aerosol dynamics, including the nucleation process, the discretisation of particle diameters starts at $1 \mathrm{~nm}$ here, and the number of sections is increased to 25. The bound diameters of the sections used in the modelling are (in $\mu \mathrm{m}$ ): 0.001 , 0.00133,0.00177, 0.00237, 0.00316, 0.00421, 0.00562, 0.00750, 0.01, 0.0141,0.01990.0282 0.0398,0.0562, 0.0794, 0.112, $0.1585,0.224,0.316,0.447,0.631,0.891,1.26,2.5,5.0,10$.

\subsection{Size distribution at emission}

Anthropogenic emissions are obtained from the Airparif 2005 inventory, which provides emissions for the different category sectors, defined by Selected Nomenclature for Air Pollution (SNAP). For particulate emissions, only PM $_{10}$ and PM 2.5 emissions are available. To determine number emissions, the size distribution of $\mathrm{PM}_{2.5}$ is estimated using ratio of $\mathrm{PM}_{1} / \mathrm{PM}_{2.5}$ and $\mathrm{PM}_{1} / \mathrm{PM}_{0.1}$ from the UK National Atmospheric Emissions Inventory (NAEI) for each activity sector. These factors are 
presented in Table A1 of Appendix A. To represent $\mathrm{PM}_{0.1}, \mathrm{PM}_{1}$ and $\mathrm{PM}_{2.5}$ emissions, the size range of diameters between $0.01 \mu \mathrm{m}$ and $10 \mu \mathrm{m}$ is divided into 5 sections regularly distributed in log-space, and of bound diameters (in $\mu \mathrm{m}$ ) $0.01,0.0398$, $0.1585,0.631,2.11,10$. Emissions of coarse particles $\left(\mathrm{PM}_{10}-\mathrm{PM}_{2.5}\right)$ are assigned to the section of diameters between 2.11 and $10 \mu \mathrm{m}$. Emissions of fine particles $\left(\mathrm{PM}_{2.5}-\mathrm{PM}_{1}\right)$ are assigned to the section of diameters between 0.631 and $2.11 \mu \mathrm{m}$. Note that 0.631 and $2.11 \mu \mathrm{m}$ are used as bound diameters for $\mathrm{PM}_{1}$ and $\mathrm{PM}_{2.5}$, because $\mathrm{PM}$ is defined for aerodynamic diameters, while the model uses the diameter of spherical particles. Aerodynamic diameters of $1 \mu \mathrm{m}$ and $2.5 \mu \mathrm{m}$ correspond to diameters of 0.631 and 2.11, assuming a particle density of $1.58 \mathrm{~g} . \mathrm{cm}^{-3}$ and approximating the Cunningham correction factor following DeCarlo et al. (2004); Jung et al. (2020). Emissions of $\mathrm{PM}_{0.1}$ are assigned in the size range of diameters between $0.01 \mu \mathrm{m}$ and $0.1585 \mu \mathrm{m}$. The bound diameter of $0.1585 \mu \mathrm{m}$ is reasonable for $\mathrm{PM}_{0.1}$ at emissions, because particles may then be irregular with a diameter larger than the aerodynamic diameter (DeCarlo et al., 2004). However, the mass of particles is redistributed arbitrarily between the low range of diameters (between $0.01 \mu \mathrm{m}$ and $0.0398 \mu \mathrm{m}$ ) and the high range (above $0.0398 \mu \mathrm{m}$ ) using a distribution coefficient $\alpha_{e m}$. The choice of this arbitrary distribution coefficient, and a sensitivity study to it, is performed in section 3. Note that particles of diameters lower than $0.01 \mu \mathrm{m}$ are not emitted here, although diesel vehicles may emit such small particles (Kuuluvainen et al., 2020). However, the work of Olin et al. (2021) suggests that these emissions may not strongly affect the number concentrations at background sites, because of the coagulation of emitted particles.

Although 5 size sections are defined for emissions, as much as 25 size sections are used in the model to represent the aerosol dynamic. To specify emissions in the range of the size sections of the model, the size distribution at emission is progressively refined by dividing each of the size section at emission into two smaller size sections, keeping both the emitted mass and number concentrations constant during each division. The algorithm used for this division is detailed in Appendix A.

\subsection{Measurements}

Concerning number concentrations, measurements were performed between 1 and 31 July 2009 at three sites: the LHVP site, a background urban site in the center of Paris, the SIRTA site, a background suburban site in the south west of Paris, and the GOLF site, a background suburban site close to a golf course in the north east of Paris (see Figure 4). At the LHVP site, the number concentrations were monitored using a Twin Differential Mobility Particle Sizer (TDMPS) for diameters between 3 and $635 \mathrm{~nm}$. An Air Ion Spectrometer (AIS) monitored the size distribution of ambient (not dried) positive and negative air ions of mobility diameters ranging from 0.8 to $40 \mathrm{~nm}$. At the GOLF site, number concentrations were monitored using an Electrical Aerosol Spectrometer (EAS) for diameters between $3 \mathrm{~nm}$ and $10000 \mathrm{~nm}$. At the SIRTA site, number concentrations were monitored using a Scanning Mobility Particle Sizer (SMPS) for diameters between 10 and $500 \mathrm{~nm}$. The monthly-average size distribution is plotted in Figures 6, 7 and 8 at the SIRTA, LHVP and GOLF sites respectively. The lowest number concentrations are measured at the suburban SIRTA site. The highest number concentrations are measured at the suburban GOLF site. Further details about the measurements performed may be found in Pikridas et al. (2015). Mass concentrations were also monitored, allowing to validate the modelled particle mass concentrations. The mass concentrations of sulfate, nitrate, ammonium and organics in $\mathrm{PM}_{1}$ were monitored with Aerosol Mass Spectrometers (Freutel et al., 2013). 


\section{Selection of non-nucleation days to determine the size distribution at emission}

The undetermined number distribution coefficient $\alpha_{e m}$ at emission, defined in section 2.2, is estimated by comparing the model to the measurements during non-nucleation days at LHVP, where measurements of UFP from diameters as low as $0.8 \mathrm{~nm}$ are available from the AIS.

5 Three sets of distribution coefficients $\alpha_{e m}$ are tested: 10-90\%, 15-85\% and 25-75\%. The differences between the size distribution at emission for these sets are shown in Figure 1. The number of UFP at emission is smaller in the set 10-90\% than in the set $15-85 \%$, which is itself smaller than in the set $25-75 \%$. The number of particles of diameters lower than $5 \mathrm{~nm}$, as measured with the AIS and with the TDMPS, is shown in Figure 2. It is the lowest at the beginning of July: it is lower than $20 \mathrm{~cm}^{-3}$ for the $2^{\text {nd }}$ and $3^{\text {rd }}$ July and for the first 6 hours of the $4^{\text {th }}$ July. This period is then selected to determine the number distribution coefficient at emission. Over that period, the averaged number concentration measured with the TDMPS consists mostly of particles of diameter larger than $10 \mathrm{~nm}\left(\mathrm{~N}_{>10}\right)$. Figure 3 compares the average number concentrations simulated over that period to the TDMPS measurements, using the different emission distribution coefficients $\alpha_{e m}: 10-90 \%, 15-85 \%$ and $25-75 \%$. The measured $\mathrm{N}_{>10}$ is $8216 \mathrm{~cm}^{-3}$, while the averaged simulated $\mathrm{N}_{>10}$ is $6172 \mathrm{~cm}^{-3}$ for the emission distribution coefficient $10-90 \%, 8152 \mathrm{~cm}^{-3}$ for the emission distribution coefficient $15-85 \%$ and $12883 \mathrm{~cm}^{-3}$ for the emission distribution coefficient $25-75 \%$. Clearly, the number of UFP is too high using the emission distribution coefficient $25-75 \%$. It shows that particles of diameters below $0.03 \mu \mathrm{m}$ are over-estimated using the emission distribution coefficient $15-85 \%$, while they are well modelled using the emission distribution coefficient $10-90 \%$.

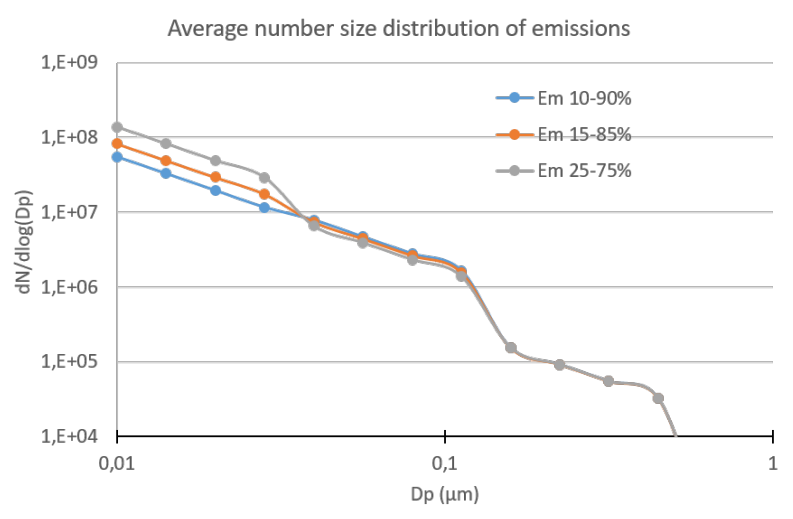

Figure 1. Number of emitted particles as a function of diameters in $\# \mathrm{~m}^{-2} \mathrm{~s}^{-1}$.

\section{Influence of nucleation}

Although nucleation has a low influence on the mass concentrations of $\mathrm{PM}_{1}, \mathrm{PM}_{2.5}$ and $\mathrm{PM}_{10}$, it has a major influence on the number concentration during July. As shown in the left panel of Figure 4, if nucleation is not taken into account, the high number concentrations are observed along the main roads and motorways, and concentrations are higher near the central part 


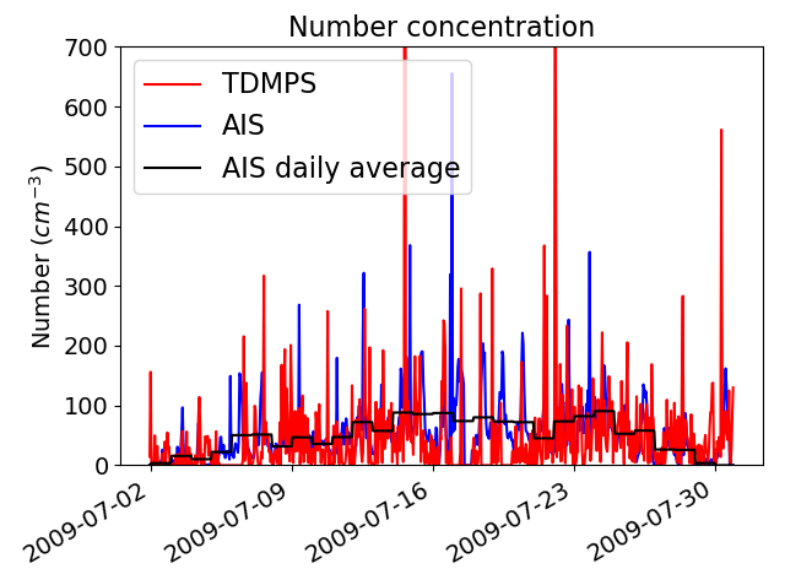

Figure 2. Number of particles of diameters lower than $5 \mathrm{~nm}$, as measured with the AIS (in blue) and with the TDMPS (in red). The black lines represents the average daily number concentrations measured with the AIS.

of the city. The main roads are clearly distinguishable on the map of number concentrations, highlighting the strong impact of traffic emissions on the simulated concentrations.

To assess the influence of nucleation, simulations are performed with different nucleation parameterisations and compared to the simulation where nucleation is ignored. The nucleation parameterisations are those detailed in section 2.1: the binary 5 nucleation parameterisation of Kuang et al. (2008) involving sulfuric acid and water, the ternary nucleation parameterisation of Napari et al. (2002) involving ammonia, sulfuric acid and water, and the heteromolecular nucleation parameterisation involving organic and sulfuric acid of Riccobono et al. (2014).

Nucleation leads to a large increase of number concentrations. In average over the whole domain and over the month of July, the binary, ternary and heteromolecular nucleation parameterisations lead to an increase by a factor 1.1, 2.1 and 2.8 respectively.

Figure 5 shows the relative differences between simulations taking into account one nucleation scheme and the simulation without nucleation. The increase of the number concentration by the binary parameterisation is very localised, mostly near central Paris. The increase of the number concentration by the ternary parameterisation is larger than by the binary, but it is as well very localised near Paris and its suburbs and near large factories. The increase of the number concentration by the heteromolecular parameterisation is the largest of the three parameterisations. Although the average increase over the domain is of the same order of magnitude than the increase due to ternary nucleation, it is less localised and more homogeneously distributed. However, as shown in the right panel of Figure 4, the highest number concentrations are simulated near the central part of Paris and along the main roads and motorways, even when the heteromolecular nucleation parameterisation is used. 

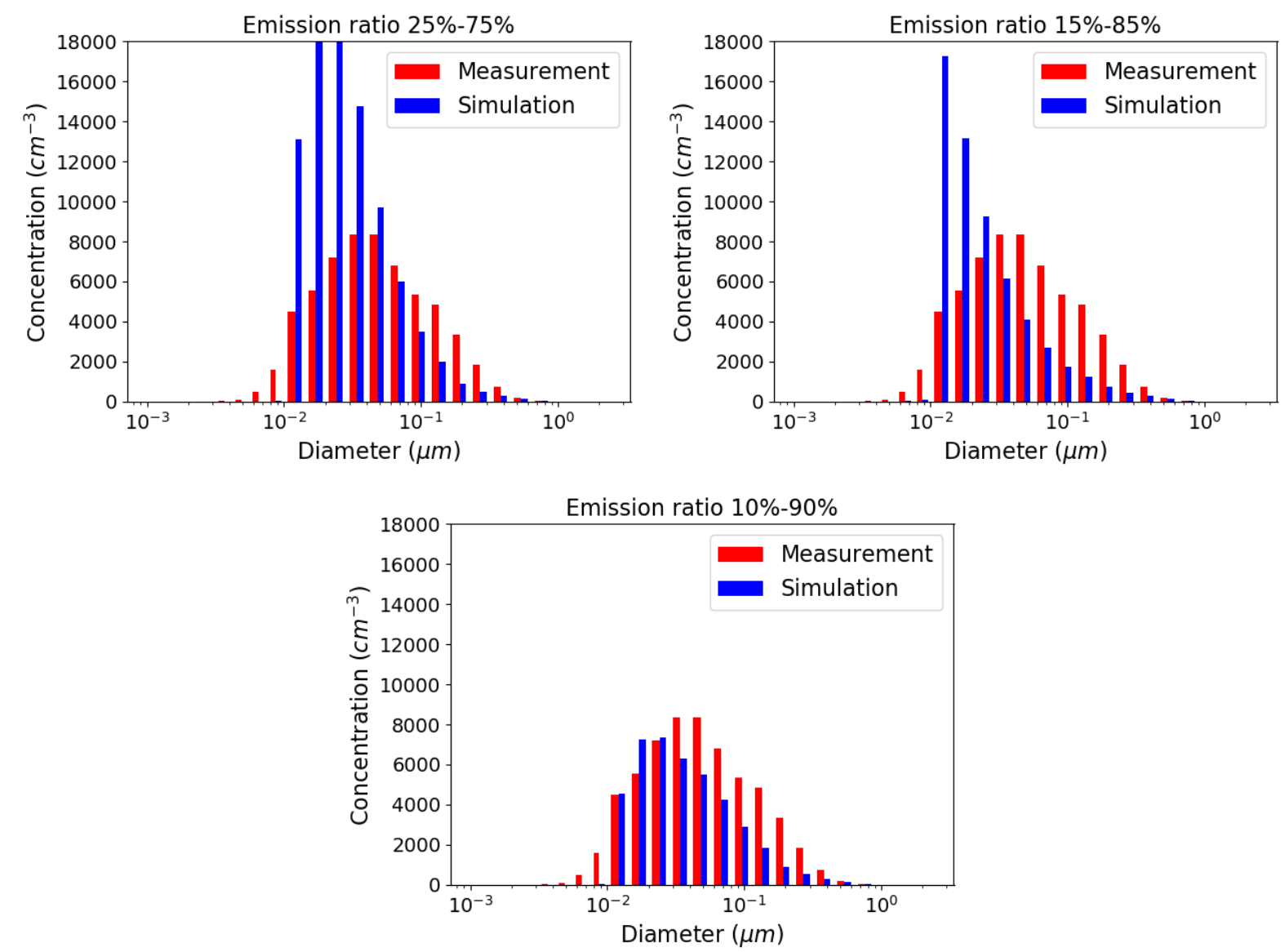

Figure 3. Average number concentration between the $2^{\text {nd }}$ July 00:00 and the $4^{\text {th }}$ July 6 am, simulated with an emission ratio of $25 \%-75 \%$ (upper left panel), 15\%-85\% (upper right panel), 10\%-90\% (lower panel). The simulated concentrations are in blue, while the concentrations measured with the TDMPS are in red.

\section{Model evaluation}

The simulated concentrations are evaluated using the measurements performed at the SIRTA, LHVP and GOLF sites.

\subsection{Statistics}

\subsubsection{Mass concentration}

5 The mass concentration of the particles and of the different compounds of particles are fairly well modelled, as shown in Table 1. $\mathrm{PM}_{2.5}$ and $\mathrm{NO}_{2}$ modelled concentrations are compared to measurements routinely carried out at background sites by the air-quality agency Airparif. For $\mathrm{PM}_{2.5}$, as well as for sulfate, ammonium and organics in $\mathrm{PM}_{1}$, the simulated concentrations satisfy the most strict performance criteria of Boylan and Russell (2006) (mean fractional error MFE below 50\% and mean 

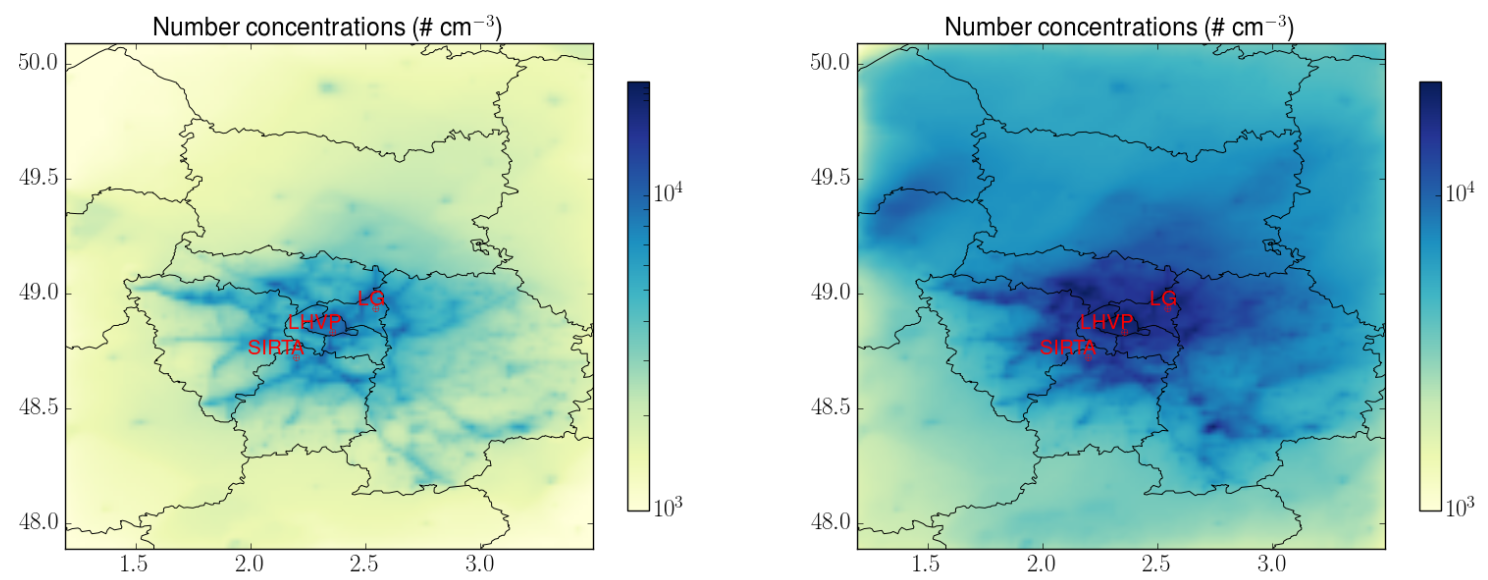

Figure 4. Number concentrations in $\# \mathrm{~cm}^{-3}$ for the simulation without nucleation (left panel) and the simulation with heteromolecular nucleation (right panel).

fractional bias MFB below 30\%). The MFE for nitrate concentration is higher (88\%), but the nitrate concentrations are very low $\left(0.2 \mu \mathrm{g} \mathrm{m}^{-3}\right)$ in both the measurements and the simulation. Except for nitrate, the correlations $\mathrm{R}$ between simulation and measurements are also high (between $57 \%$ and $76 \%$ ).

Note that the statistics shown in Table 1 are not influenced by the nucleation scheme.

Table 1. Model to measurement comparisons of daily mass concentrations in July 2009.

\begin{tabular}{ccccccc} 
& $\mathrm{NO}_{2}$ & $\mathrm{PM}_{2.5}$ & Sulfate $_{1}$ & Nitrate $_{1}$ & Ammonium $_{1}$ & Organics $_{1}$ \\
\hline Number of stations & 46 & 5 & 3 & 3 & 3 & 3 \\
\hline Meas. mean $\left(\mu \mathrm{g} \mathrm{m}^{-3}\right)$ & 15.8 & 10.3 & 1.0 & 0.2 & 0.4 & 2.9 \\
Sim. mean $\left(\mu \mathrm{g} \mathrm{m}^{-3}\right)$ & 14.1 & 8.2 & 0.9 & 0.2 & 0.4 & 2.4 \\
\hline MFB $(\%)$ & -21 & -19 & -14 & -20 & 3 & -5 \\
MFE $(\%)$ & 41 & 33 & 34 & 88 & 29 & 36 \\
Correlation $(\%)$ & 73 & 76 & 69 & 32 & 74 & 57
\end{tabular}

\section{5.1.2 Number concentration}

The simulated number concentrations of particles of diameter larger than $10 \mathrm{~nm}\left(\mathrm{~N}_{>10}\right)$ and $100 \mathrm{~nm}\left(\mathrm{~N}_{>100}\right)$ are compared to the observations at SIRTA, LHVP and GOLF in Table 2. The simulation without nucleation strongly underestimates the number concentrations $\mathrm{N}_{>10}$ and $\mathrm{N}_{>100}$ in July 2009 at all sites (SIRTA, LHVP and GOLF). There are no established criteria for determining how well a simulation performs against the measurement. The normalised mean bias (NMB) and the normalised mean error (NME) are often used (Fanourgakis et al., 2019; Olin et al., 2021; Patoulias and Pandis, 2021; Frohn et al., 2021). 



Figure 5. Differences in number concentrations in \% between simulations with nucleation and without. The nucleation parameterisations used are respectively the heteromolecular on the top left panel, the binary on the top right panel and the ternary on the bottom panel.

For a month of spring/summer over Europe, in Olin et al. (2021) the NME was $94 \%$ for $\mathrm{N}_{>10}$ and $49 \%$ for $\mathrm{N}_{>100}$ in average over 6 stations; in Patoulias and Pandis (2021) the NME was $63 \%$ for $\mathrm{N}_{>10}$ and $45 \%$ for $\mathrm{N}_{>100}$ on average over 26 stations. The NMB of $\mathrm{N}_{>30}$ ranged between $117 \%$ and $161 \%$ in Frohn et al. (2021), who used a modal approach for the size distribution. Simulations over cities led to higher errors: only monthly-means are compared in Kukkonen et al. (2016) and the NMB range between 218\% and 285\% for $\mathrm{N}_{>30}$ in Frohn et al. (2021). The simulations without nucleation presented here lie in the range of errors obtained in previous studies at the European scale with NMEs between $36 \%$ and $79 \%$ for $\mathrm{N}_{>10}$ and between $47 \%$ and $50 \%$ for $\mathrm{N}_{>100}$. Theses statistics are improved when nucleation is used, depending on the nucleation scheme used. Using the heteromolecular scheme for nucleation leads to very good model to measurement comparisons: the NME is $42 \%$ in average for $\mathrm{N}_{>10}$ and $37 \%$ for $\mathrm{N}_{>100}$.

The effect of the binary nucleation is very low, especially for $N_{>100}$ at all sites. There is almost no change in the statistics at the SIRTA suburban site for both $N_{>100}$ and $N_{>10}$. The effect of nucleation is the largest at the site in Paris center (LHVP), 
where it leads to an increase of the number of particules and reduces the bias from $-54 \%$ to $-42 \%$. However the error slighly increases and the correlation stronly decreases (fom 68\% to 26\%), suggesting that the binary nucleation scheme does not improve the model to measurement comparisons overall. At all sites, the number concentration is strongly underestimated if only binary nucleation is taken into account.

The effect of the ternary nucleation is higher than the effect of the binary one. For $N_{>100}$, the number concentration increases leading to a decrease of the bias, as well as a decrease of the error. This decrease is the strongest at the GOLF site, reducing the bias from $-50 \%$ to $-41 \%$ and the error from $50 \%$ to $44 \%$. However, the model to measurement correlation decreases strongly at GOLF site from 50\% to 37\%. Although the correlation also decreases because of ternary nucleation at the LHVP site, it increases from $51 \%$ to $59 \%$ at the SIRTA site. For $N_{>10}$, The increase of number concentration leads to an decrease of the bias and error at both the SIRTA and GOLF sites. As for $N_{>100}$, this decrease is the strongest at the GOLF site where the bias is reduced from $-79 \%$ to $-24 \%$ and the error is reduced from $79 \%$ to $51 \%$. At the LHVP site in central Paris, the increase in $N_{>10}$ is too strong, the absolute value of the bias is not much modified: it varies from $-54 \%$ to $55 \%$, but the error increases from $55 \%$ to $97 \%$. At all three sites, the correlation strongly decreases. The effect of the parameterisation is not completely satisfactory, because although the measurement-model bias decreases at most sites, the nucleation is too strong at the site located in the center of Paris and the measurement-model correlations decrease strongly.

The effect of the heteromolecular nucleation strongly improves the bias and error of $N_{>100}$ and $N_{>10}$ at all sites. For example, at the SIRTA site, for $N_{>10}$, the bias is reduced from $-54 \%$ to $-17 \%$ and the error from $54 \%$ to $36 \%$; for $N_{>100}$, the bias is reduced from $-44 \%$ to $-28 \%$ and the error from $47 \%$ to $36 \%$. For $N_{>10}$, the correlation is not much modified, except at the LHVP site where it is reduced from $68 \%$ to $49 \%$. However the correlation decreases less than with the other nucleation schemes (it decreases to $26 \%$ for the binary nucleation and to $-20 \%$ for the ternary nucleation). For $N_{>100}$, the correlation also slightly decreases at the LHVP site from $77 \%$ to $68 \%$, but it is greatly improved at both the SIRTA site (from 50\% to $65 \%$ ) and the GOLF site (from 51\% to 63\%). These comparisons suggest that the heteromolecular nucleation improves the modelling of $N_{>10}$ and $N_{>100}$ at the suburban sites. Even though the bias and error are also improved at the city center site, the decrease of the correlation when the nucleation parameterisations are used may indicate the need to better characterize new particle formation in cities and close to traffic sites. 
Table 2. Model to measurement comparisons of daily number concentrations of particles of diameter higher than $10 \mathrm{~nm}$ in July 2009 at LHVP, SIRTA and GOLF. $\bar{o}$ and $\bar{s}$ stand for mean observation and simulated concentrations respectively; Corr. stands for correlation; NMB and NME stand for normalised mean bias and normalised mean error respectively.

\begin{tabular}{|c|c|c|c|c|c|c|c|c|c|c|}
\hline & \multicolumn{5}{|c|}{$\mathrm{N}_{>10}$} & \multicolumn{5}{|c|}{$\mathrm{N}_{>100}$} \\
\hline & $\bar{o}$ & $\bar{s}$ & Corr. & NMB & NME & $\bar{o}$ & $\bar{s}$ & Corr. & NMB & NME \\
\hline Station & \multicolumn{10}{|c|}{ SIRTA } \\
\hline No nucl. & 5328 & 2458 & 48 & -54 & 54 & 946 & 532 & 51 & -44 & 47 \\
\hline Binary & 5328 & 2461 & 47 & -54 & 54 & 946 & 531 & 51 & -44 & 47 \\
\hline Ternary & 5328 & 3241 & 27 & -39 & 51 & 946 & 571 & 59 & -40 & 43 \\
\hline Heteromolecular & 5328 & 4396 & 49 & -17 & 36 & 946 & 680 & 65 & -28 & 36 \\
\hline Station & \multicolumn{10}{|c|}{ LHVP } \\
\hline No nucl. & 9852 & 4567 & 68 & -54 & 55 & 1191 & 667 & 77 & -44 & 47 \\
\hline Binary & 9852 & 5709 & 26 & -42 & 57 & 1191 & 660 & 76 & -44 & 47 \\
\hline Ternary & 9852 & 15302 & -20 & 55 & 97 & 1191 & 713 & 68 & -40 & 44 \\
\hline Heteromolecular & 9852 & 7341 & 49 & -25 & 37 & 1191 & 805 & 68 & -32 & 38 \\
\hline Station & \multicolumn{10}{|c|}{ GOLF } \\
\hline No nucl. & 12957 & 2279 & 66 & -79 & 79 & 1221 & 615 & 50 & -50 & 50 \\
\hline Binary & 12957 & 3195 & 23 & -75 & 75 & 1221 & 625 & 47 & -49 & 49 \\
\hline Ternary & 12957 & 9739 & -51 & -24 & 51 & 1221 & 716 & 37 & -41 & 44 \\
\hline Heteromolecular & 12957 & 5814 & 64 & -55 & 55 & 1221 & 808 & 63 & -33 & 37 \\
\hline
\end{tabular}

\subsection{Size distribution}

The strong influence of nucleation is also evident by looking at the particle size distributions averaged over the month of July in Figure 6 at the SIRTA site, Figure 7 at the LHVP site, and Figure 8 at the GOLF site.

At the SIRTA site, Figure 6 shows that the influence of binary nucleation is very low. The influence of ternary nucleation

5 is higher, but the number of particles of diameters between $20 \mathrm{~nm}$ and $200 \mathrm{~nm}$ is strongly underestimated. This number is better modelled using the heteromolecular nucleation parameterisation, although this parameterisation seems to overestimate the number of particles between 10 and $20 \mathrm{~nm}$.

At the LHVP site, Figure 7 shows that the influence of the binary nucleation is higher than at the SIRTA site, and leads to good model to measurement comparisons, although the number of particles of diameters between 20 and $200 \mathrm{~nm}$ are underestimated. This under-estimation is less important using the heteromolecular parameterisation, which leads to an overestimation of the number of particles between 3 and $10 \mathrm{~nm}$. The ternary nucleation parameterisation performs well for number of particles of diameters above $20 \mathrm{~nm}$, but the number of particles of diameter below $20 \mathrm{~nm}$ is strongly over-estimated (by a factor larger than 100). 
At the GOLF site, Figure 7 shows that the number concentration is strongly underestimated if nucleation is not taken into account for particles of all diameters. The effect of binary nucleation is very small. The heteromolecular nucleation parameterisation perfoms better. Although it leads to acceptable statistics, the number concentration is still under-estimated for particles of all diameters. A good representation of the size distribution is obtained using the ternary nucleation parameterisation.
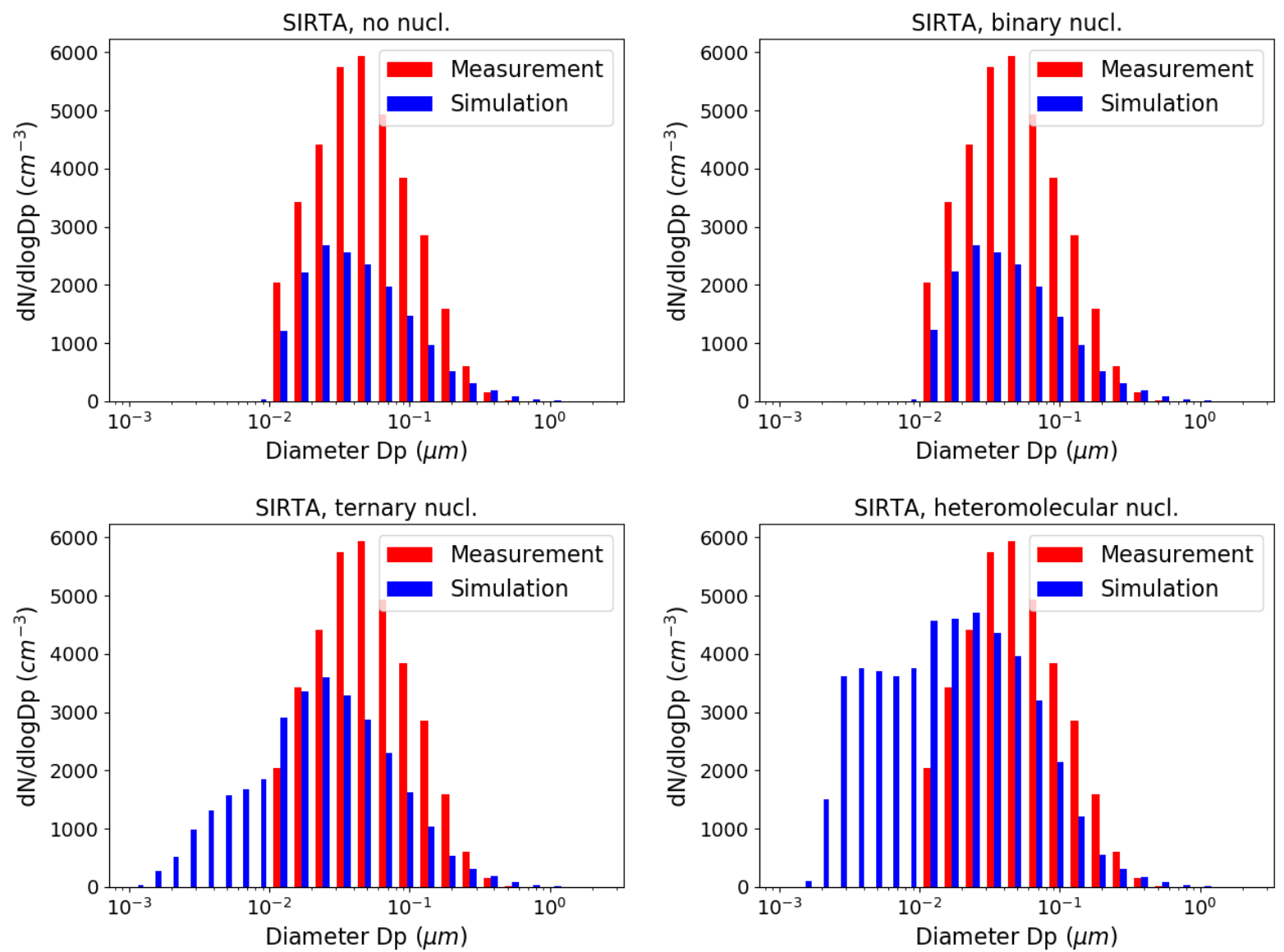

Figure 6. Size distribution of the number concentrations in $\# \mathrm{~cm}^{-3}$ at the SIRTA site for the simulation without nucleation (top left panel), with binary nucleation (top right panel), ternary nucleation (bottom left panel), heteromolecular nucleation (bottom right panel).

\section{Conclusion}

This paper illustrates a method for estimating the number emission factors and the size distribution for the different activity sectors from the emissions of $\mathrm{PM}_{2.5}$. The estimated size distribution at emissions is discretised using a sectional approach and it is refined ensuring consistency of both mass and number concentrations. This method is applied over Greater Paris and calibrated using days when nucleation was low. 

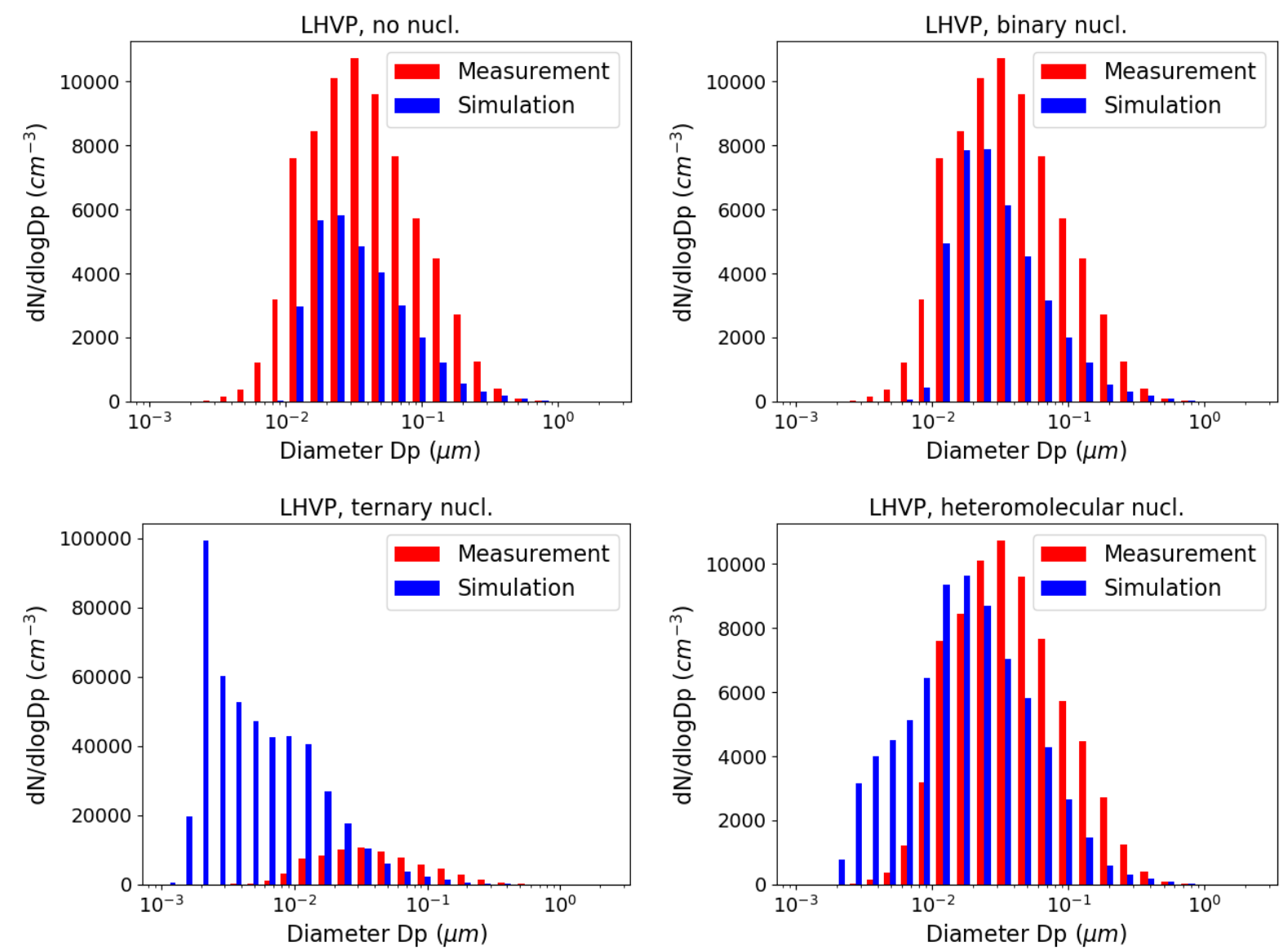

Figure 7. Size distribution of the number concentrations in $\# \mathrm{~cm}^{-3}$ at the LHVP site for the simulation without nucleation (top left panel), with binary nucleation (top right panel), ternary nucleation (bottom left panel), heteromolecular nucleation (bottom right panel).

$\mathrm{PM}_{1}, \mathrm{PM}_{2.5}$ and $\mathrm{PM}_{10}$ concentrations are not influenced by nucleation. But nucleation has a strong influence on the number concentration in July 2009. The influence of binary nucleation, which involves sulfuric acid and water, is low over Paris. The influence of ternary nucleation, which involves sulfuric acid, ammonia and water, can be very high, but this high influence may not be realistic. It leads to very good model to measurement comparison at one suburban site, in terms of size distribution, but systematically deteriorates the correlation between simulated and measured number concentrations. Furthermore, it strongly overestimates the number concentrations at the central site, and slightly underestimate it at the other suburban site. Co-located measurements of ammonia and number concentrations are required to conclude on the role of ammonia in nucleation in urban areas. The best model to measurement comparisons for $\mathrm{N}_{>10}, \mathrm{~N}_{>100}$ and the size distribution are obtained using the heteromolecular nucleation parameterisation, which involves sulfuric acid and extremely low-volatile organic compounds from monoterpenes, emphasising the realistic importance of this process. 

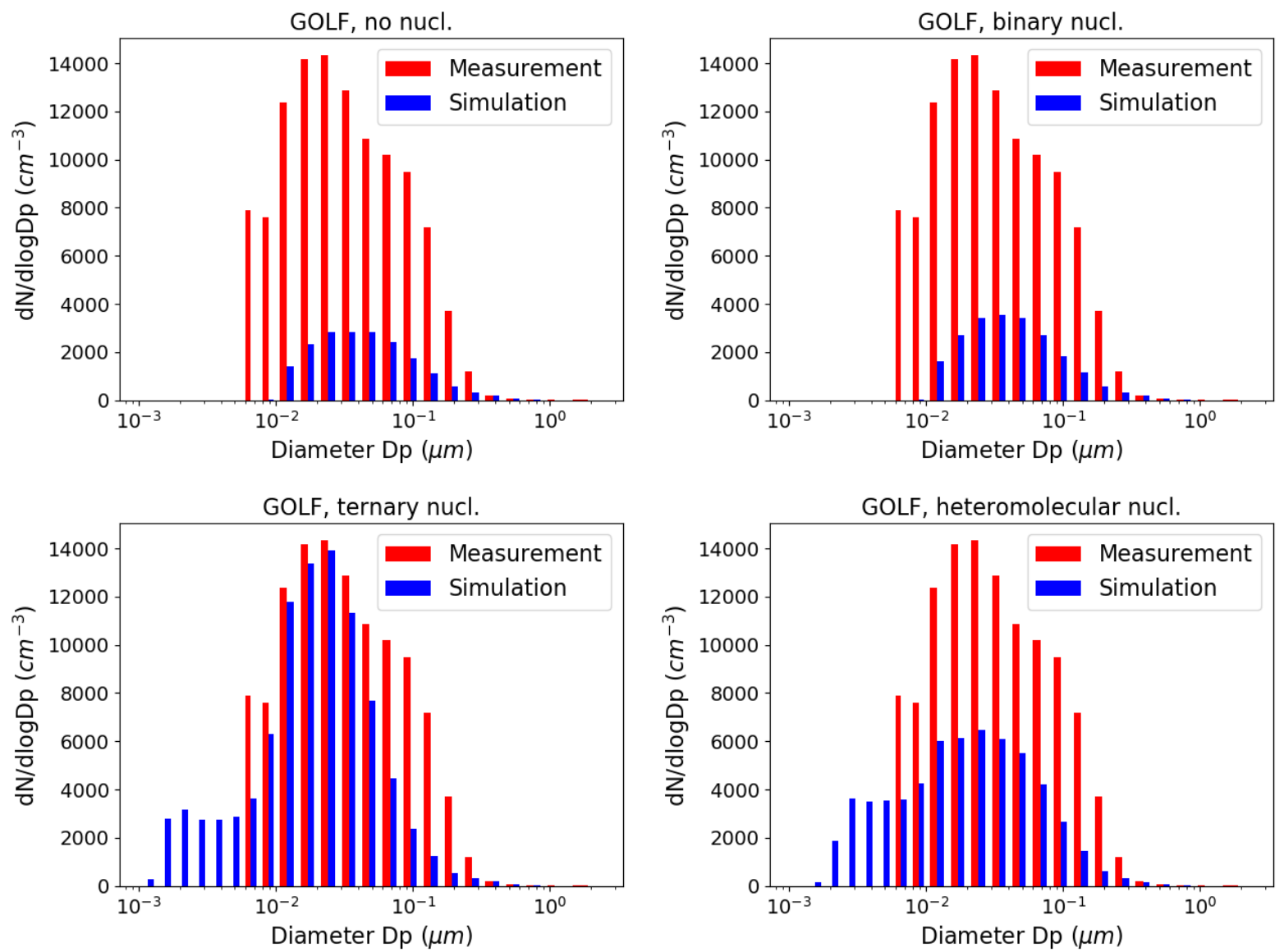

Figure 8. Size distribution of the number concentrations in $\# \mathrm{~cm}^{-3}$ at the GOLF site for the simulation without nucleation (top left panel), with binary nucleation (top right panel), ternary nucleation (bottom left panel), heteromolecular nucleation (bottom right panel).

The correlation between measured and simulated number concentrations is high for the simulation without nucleation (higher than $48 \%$ ) stressing the strong influence of primary emissions. At the two suburban sites, the heteromolecular nucleation parameterisation clearly leads to improved simulated number concentrations compared to measurements, with lower error, bias and higher correlation. The correlation is systematically deteriorated at the central site (LHVP) if nucleation is taken into account, suggesting that nucleation may involve other species than those used here, or that monoterpene emissions from traffic could be underestimated. Guo et al. (2020) suggested that extremely low-volatile compounds (ELVOC) formed from traffic emissions or emitted by traffic could nucleate. Recent studies suggested that traffic may emit monoterpenes, such as $\alpha$-pinene (Panopoulou et al., 2020), which could then formed ELVOC rapidly and be involved in nucleation. 
https://doi.org/10.5194/acp-2022-22

Preprint. Discussion started: 17 January 2022

(C) Author(s) 2022. CC BY 4.0 License.

(c) (1)

\section{Competing interests}

The authors declare that they have no conflict of interest.

\section{Acknowledgments}

The emission data used to estimate the size-distribution of particles at emissions were obtained from the web site naei.beis.gov.uk 5 (@Crown 2021 copyright Defra \& BEIS via naei.beis.gov.uk, licenced under the Open Government Licence (OGL)). The work was supported partly by ERA-PLANET (www.era-planet.eu), trans-national project SMURBS (www.smurbs.eu, grant agreement n. 689443) and Research Infrastructures Services Reinforcing Air Quality Monitoring Capacities in European Urban \& Industrial AreaS (RI-URBANS,101036245). Thanks are due to Airparif, the Paris region air quality agency, for providing us with their air pollutant emission inventory; Evangelia Kostenidou for the SMPS measurements at the SIRTA site, and Friederike

10 Fachinger and Johannes Schneider (Max Planck Institute for Chemistry, Germany) for the measurements at the GOLF site. 


\section{Appendix A: Size distribution of emissions}

To estimate the size-distribution of emissions, emissions of $\mathrm{PM}_{1}, \mathrm{PM}_{0.1}$ are deduced from emissions of $\mathrm{PM}_{2.5}$ using the ratios of Table A1.

Then the discretisation of the size sections of the emitted particles is refined by assuming that both mass and number are

5 kept constant in each diameter range. As an illustration, let us consider one section of bound diameters $d_{\text {inf }}$ and $d_{\text {sup }}$, i.e. all particles in that section have diameters between $d_{\text {inf }}$ and $d_{\text {sup }}$ (for example, $d_{\text {inf }}=0.1 \mu \mathrm{m}$ and $d_{\text {sup }}=1 \mu \mathrm{m}$ ). These particles of diameters between $d_{i n f}$ and $d_{\text {sup }}$ are assumed to have a mass $\mathrm{M}$ and a number of particles $\mathrm{N}$. To refine the section discretisation into 2 sections rather than one, a bound diameter $d_{\text {new bound }}$ is added between $d_{\text {inf }}$ and $d_{\text {sup }}$. This allows to define two sections: section one for particles of diameters between $d_{\text {inf }}$ and $d_{\text {new bound }}$ and section two for particles between $d_{\text {new bound }}$ and $d_{\text {sup }}$. The particles of section 1 have diameters between $d_{\text {inf }}$ and $d_{\text {new bound }}$, and they are assumed to have a mass $\mathrm{M}_{1}$ and a number of particles $\mathrm{N}_{1}$. The particles of section 2 have diameters between $d_{\text {new bound }}$ and $d_{\text {sup }}$, and they are assumed to have a mass $\mathrm{M}_{2}$ and a number of particles $\mathrm{N}_{2}$. By assuming that refining the discretisation conserves both mass and number $\left(\mathrm{M}=\mathrm{M}_{1}+\mathrm{M}_{2} ; \mathrm{N}=\mathrm{N}_{1}+\mathrm{N}_{2}\right)$, and that the mean diameter of each section is the geometrical mean of the section, then the mass $\mathrm{M}_{1}$ and $\mathrm{M}_{2}$ may be written as

$M_{1}=\frac{1}{1+a} M ; \quad M_{2}=\frac{a}{1+a} M$ with: $a=\frac{\frac{1}{d_{\text {new bound }}^{3 / 2}-\frac{1}{d_{\text {inf }}^{3 / 2}}}}{\frac{1}{d_{\text {sup }}^{3 / 2}-\frac{1}{d_{\text {new bound }}^{3 / 2}}}}$

The number of particles of each section is then deduced from the mass, the density and the geometric mean diameter $\bar{d}$ of the section by assuming that particles are spherical:

$$
N_{1}=\frac{6 M_{1}}{\pi \rho \bar{d}_{1}} ; N_{2}=\frac{6 M_{2}}{\pi \rho \bar{d}_{2}}
$$


Table A1. Estimation of the size-distribution of emissions by estimating the ratio $\mathrm{PM}_{1} / \mathrm{PM}_{2.5}$ and $\mathrm{PM}_{0.1} / \mathrm{PM}_{1}$ for each activity sector.

\begin{tabular}{|c|c|c|c|}
\hline & SNAP & $\mathrm{PM}_{1} / \mathrm{PM}_{2.5}$ & $\mathrm{PM}_{0.1} / \mathrm{PM}_{1}$ \\
\hline Combustion in energy and transformation industries & 01 & & \\
\hline Public power and District heating plants & 0101/0102 & 0.7945 & 0.4806 \\
\hline Petroleum refining plants & 0103 & 0.8058 & 0.5428 \\
\hline Stationary engines & 0105 & 1 & 0.5 \\
\hline Non-industrial combustion plants & 02 & & \\
\hline Commercial and institutional plants & 0201 & 0.8577 & 0.4155 \\
\hline Residential plants & 0202 & 0.6761 & 0.2006 \\
\hline Plants in agriculture, forestry and aquaculture & 0203 & 0.7101 & 0.5565 \\
\hline Combustion in manufacturing industry & 03 & 0.8072 & 0.5265 \\
\hline Production processes & 04 & & \\
\hline Processes in petroleum industries & 0401 & 0.8072 & 0.5265 \\
\hline Processes in iron and steel industries and colliries & 0402 & 0.5117 & 0.3684 \\
\hline $\begin{array}{c}\text { Processes in inorganic and organic chemical industries, } \\
\text { wood, food and other }\end{array}$ & 0404/0405/0406 & 0.7711 & 0.5 \\
\hline Extraction and distribution of fossil fuels and geothermal energy & 05 & 0.8072 & 0.5265 \\
\hline Solvent and other product use & 06 & 0.7711 & 0.5 \\
\hline Road transport & 07 & & \\
\hline Passenger cars, light, heavy duty vehicles and buses & 0701/0702/0703 & 0.8947 & 0.5882 \\
\hline Mopeds and Motorcycles $<50 \mathrm{~cm} 3$ and $>50 \mathrm{~cm} 3$ & 0704/0705 & 0.6842 & 0.3846 \\
\hline Gasoline evaporation from vehicles & 0706 & 0.8947 & 0.5882 \\
\hline Other mobile sources and machinery & 08 & & \\
\hline Railways & 0802 & 0.8947 & 0.1765 \\
\hline Inland waterways & 0803 & 0.8975 & 0.3032 \\
\hline Air traffic & 0805 & 0.67 & 0.2239 \\
\hline Agriculture and Forestry & 0806/0807 & 0.8148 & 0.2575 \\
\hline Industry & 0808 & 1 & 0.5 \\
\hline Household and gardening & 0809 & 0.9043 & 0.5882 \\
\hline Waste treatment and disposal & 09 & 1 & 0.15 \\
\hline Agriculture & 10 & 1 & 0.5 \\
\hline
\end{tabular}




\section{References}

Albriet, A., Sartelet, K., Lacour, S., Carissimo, B., and Seigneur, C.: Modelling aerosol number distributions from a vehicle exhaust with an aerosol CFD model., Atmos. Environ., 44, 1126-1136, 2010.

Blichner, S., Sporre, M., Makkonen, R., and Berntsen, T.: Implementing a sectional scheme for early aerosol growth from new particle formation in the Norwegian Earth System Model v2: comparison to observations and climate impacts, Geosci. Mod. Dev., 14, 3335-3359, https://doi.org/10.5194/gmd-14-3335-2021, 2021.

Boylan, J. and Russell, A.: PM and light extinction model performance metrics, goals, and criteria for three-dimensional air quality models, Atmos. Environ., 40, 4946-4959, https://doi.org/10.1016/j.atmosenv.2005.09.087, 2006.

Casquero-Vera, J., Lyamani, H., Titos, G., de A. Moreira, G., Benavent-Oltra, J., Conte, M., Contini, D., Järvi, L., Olmo-Reyes, F., and Alados-Arboledas, L.: Aerosol number fluxes and concentrations over a southern European urban area, Atmos. Environ., 269, 118 849, https://doi.org/10.1016/j.atmosenv.2021.118849, 2022.

Chrit, M., Sartelet, K., Sciare, J., Pey, J., Marchand, N., Couvidat, F., Sellegri, K., and Beekmann, M.: Modelling organic aerosol concentrations and properties during ChArMEx summer campaigns of 2012 and 2013 in the western Mediterranean region, Atmos. Chem. Phys., 17, 12 509-12 531, https://doi.org/10.5194/acp-17-12509-2017, 2017.

Couvidat, F., Debry, É., Sartelet, K., and Seigneur, C.: A hydrophilic/hydrophobic organic $\left(\mathrm{H}^{2} \mathrm{O}\right)$ aerosol model: Development, evaluation and sensitivity analysis., J. Geophys. Res., 117, https://doi.org/10.1029/2011JD017214, 2012.

Couvidat, F., Kim, Y., Sartelet, K., Seigneur, C., Marchand, N., and Sciare, J.: Modeling secondary organic aerosol in an urban area: application to Paris , Atmos. Chem. Phys., 13, 983-996, https://doi.org/10.5194/acp-13-983-2013, 2013.

de Jesus, A., Rahman, M., Mazaheri, M., Thompson, H., Knibbs, L., Jeong, C., Evans, G., Nei, W., Ding, A., Qiao, L., Li, L., Portin, H., Niemi, J., Timonen, H., Luoma, K., Petäjä, T., Kulmala, M., Kowalski, M., Peters, A., Cyrys, J., Ferrero, L., Manigrasso, M., Avino, P., Buonano, G., Reche, C., Querol, X., Beddows, D., Harrison, R., Sowlat, M., Sioutas, C., and L., M.: Ultrafine particles and PM2.5 in the air of cities around the world: Are they representative of each other?, Environ Int., 129, 118-135, https://doi.org/10.1016/j.envint.2019.05.021, 2019.

DeCarlo, P., Slowik, J., Worsnop, D., Davidovits, P., and Jimenez, J.: Particle Morphology and Density Characterization by Combined Mobility and Aerodynamic Diameter Measurements. Part 1: Theory, Aerosol Sc. and Tech., 38, 1185-1205, https://doi.org/10.1080/027868290903907, 2004.

Devilliers, M., Debry, E., Sartelet, K., and Seigneur, C.: A new algorithm to solve condensation/evaporation for ultra fine, fine, and coarse particles, J. Atmos. Sci., 55, 116-136, 2013.

Downward, G., van Nunen, E., Kerckhoffs, J., Vineis, P., Brunekreef, B., Boer, J., Messier, K., Roy, A., Verschuren, W., van der Schouw, Y., Sluijs, I., Gulliver, J., Hoek, G., and Vermeulen, R.: Long-Term Exposure to Ultrafine Particles and Incidence of Cardiovascular and Cerebrovascular Disease in a Prospective Study of a Dutch Cohort., Environ Health Perspect., 126, 127 007, https://doi.org/10.1289/EHP3047, 2018.

Ehn, M., Thornton, J., Kleist, E., Sipilä, M., Junninen, H., Pullinen, I., Springer, M., Rubach, F., Tillmann, R., Lee, B., Lopez-Hilfiker, F., Andres, S., Acir, I., Rissanen, M., Jokinen, T., Schobesberger, S., Kangasluoma, J., Kontkanen, J., Nieminen, T., Kurtén, T., Nielsen, L. B., Jørgensen, S., Kjaergaard, H. G., Canagaratna, M., Dal Maso, M., Berndt, T., Petäjä, T., Wahner, A., Kerminen, V., Kulmala, M., Worsnop, D. R., Wildt, J., and Mentel, T. F.: A large source of low-volatility secondary organic aerosol, Nature, 506, 476-479, https://doi.org/10.1038/nature13032, 2014. 
EMEP/EEA: EMEP/EEA air pollutant emission inventory guidebook 2019, EEA Report No 13/2019, European Environment Agency, https: //www.eea.europa.eu/publications/emep-eea-guidebook-2019 (access 2021-06-18), 2019.

Fanourgakis, G., Kanakidou, M., Nenes, A., Bauer, S., Bergman, T., Carslaw, K., Grini, A., Hamilton, D., Johnson, J., Karydis, V., Kirkevag, A., Kodros, J., Lohmann, U., Luo, G., Makkonen, R., Matsui, H., Neubauer, D., Pierce, J., Schmale, J., Stier, P., Tsigaridis, K., van Noije, T., Wang, H., Watson-Parris, D., Westervelt, D., Yang, Y., Yoshioka, M., Daskalakis, N., Decesari, S., Gysel-Beer, M., Kalivitis, N., Liu, X., Mahowald, N., Myriokefalitakis, S., Schrödner, R., Sfakianaki, M., Tsimpidi, A., Wu, M., and Yu, F.: Evaluation of global simulations of aerosol particle and cloud condensation nuclei number, with implications for cloud droplet formation, Atmos. Chem. Phys., 19, 8591-8617, https://doi.org/10.5194/acp-19-8591-2019, 2019.

Fountoukis, C., Riipinen, I., Denier van der Gon, H., Charalampidis, P., Pilinis, C., and Pandis, S.: Simulating ultrafine particle formation in Europe using a regional CTM : Contribution of primary emissions versus secondary formation to aerosol number concentrations., Atmos. Chem. Phys., 12, 8663-8677, https://doi.org/10.5194/acp-12-8663-2012, 2012.

Freutel, F., Schneider, J., Drewnick, F., von der Weiden-Reinmüller, S.-L., Crippa, M., Prévôt, A. S. H., Baltensperger, U., Poulain, L., Wiedensohler, A., Sciare, J., Sarda-Estève, R., Burkhart, J. F., Eckhardt, S., Stohl, A., Gros, V., Colomb, A., Michoud, V., Doussin, J. F., Borbon, A., Haeffelin, M., Morille, Y., Beekmann, M., and Borrmann, S.: Aerosol particle measurements at three stationary sites in the megacity of Paris during summer 2009: meteorology and air mass origin dominate aerosol particle composition and size distribution, Atmos. Chem. Phys., 13, 933-959, https://doi.org/10.5194/acp-13-933-2013, 2013.

Frohn, L. M., Ketzel, M., Christensen, J. H., Brandt, J., Im, U., Massling, A., Andersen, C., Plejdrup, M. S., Nielsen, O.-K., van der Gon, H. D., Manders-Groot, A., and Raaschou-Nielsen, O.: Modelling ultrafine particle number concentrations at address resolution in Denmark from 1979-2018 Part 1: Regional and urban scale modelling and evaluation, Atmos. Environ., 264, 118631, https://doi.org/10.1016/j.atmosenv.2021.118631, 2021.

Guo, S., Hu, M., Peng, J., Wu, Z., Zamora, M. L., Shang, D., Du, Z., Zheng, J., Fang, X., Tang, R., Wu, Y., Zeng, L., Shuai, S., Zhang, W., Wang, Y., Ji, Y., Li, Y., Zhang, A. L., Wang, W., Zhang, F., Zhao, J., Gong, X., Wang, C., Molina, M. J., and Zhang, R.: Remarkable nucleation and growth of ultrafine particles from vehicular exhaust, Proc. Nat. Acad. Sci., 117, 3427-3432, https://doi.org/10.1073/pnas.1916366117, 2020.

Jung, C., Yoon, Y., Um, J., Lee, S., Lee, J., Chiao, S., and Kim, Y.: Approximation of most penetrating particle size for fibrous filters considering Cunningham slip correction factor, Env. Eng. Res., 25, 439-445, https://doi.org/10.4491/eer.2019.058, 2020.

Jung, J., Fountoukis, C., Adams, P. J., and Pandis, S. N.: Simulation of in situ ultrafine particle formation in the eastern United States using PMCAMx-UF, J. Geophys. Res., 115, https://doi.org/https://doi.org/10.1029/2009JD012313, 2010.

Karl, M., Kukkonen, J., Keuken, M. P., Lützenkirchen, S., Pirjola, L., and Hussein, T.: Modeling and measurements of urban aerosol processes on the neighborhood scale in Rotterdam, Oslo and Helsinki, Atmos. Chem. Phys., 16, 4817-4835, https://doi.org/10.5194/acp-16-48172016, 2016.

Karl, M., Pirjola, L., Karppinen, A., Jalkanen, J.-P., Ramacher, M. O. P., and Kukkonen, J.: Modeling of the Concentrations of Ultrafine Particles in the Plumes of Ships in the Vicinity of Major Harbors, Int. J. Environ. Res. Public Health, 17, https://doi.org/10.3390/ijerph17030777, 2020.

Kelly, J., Avise, J., Cai, C., and Kaduwela, A.: Simulationg particle size distributions over California and impact on lung deposition fraction., Aerosol Sc. and Tech., 45, 148-162, 2011.

Ketzel, M., Frohn, L. M., Christensen, J. H., Brandt, J., Massling, A., Andersen, C., Im, U., Jensen, S. S., Khan, J., Nielsen, O.-K., Plejdrup, M. S., Manders, A., Denier van der Gon, H., Kumar, P., and Raaschou-Nielsen, O.: Modelling ultrafine particle number concentrations 
at address resolution in Denmark from 1979 to 2018 - Part 2: Local and street scale modelling and evaluation, Atmos. Environ., 264, 118 633, https://doi.org/10.1016/j.atmosenv.2021.118633, 2021.

Kim, Y., Couvidat, F., Sartelet, K., and Seigneur, C.: Comparison of different gas-phase mechanisms and aerosol modules for simulating particulate matter formation, J. Air Waste Manage. Assoc., 61, 1218-1226, https://doi.org/10.1080/10473289.2011.603999, 2011.

5 Kuang, C., McMurry, P., McCormick, A., and Eisele, F.: Dependence of nucleation rates on sulfuric acid vapor concentration in diverse atmospheric locations, J. Geophys. Res., 113, https://doi.org/10.1029/2007JD009253, 2008.

Kukkonen, J., Karl, M., Keuken, M., Denier van der Gon, H., Denby, B., Singh, V., Douros, J., Manders, A., Samaras, Z., Moussiopoulos, N., Jonkers, S., Aarnio, M., Karppinen, A., Kangas, L., Lützenkirchen, S., Petäjä, T., Vouitsis, I., and Sokhi, R.: Modelling the dispersion of particle numbers in five European cities, Geosci. Mod. Dev., 9, 451-478, https://doi.org/10.5194/gmd-9-451-2016, 2016.

Kulmala, M., Laaksonen, A., and Pirjola, L.: Parameterizations for sulfuric acid/water nucleation rates, J. Geophys. Res., 103, 8301-8307, https://doi.org/10.1029/97JD03718, 1998.

Kulmala, M., Asmi, A., Lappalainen, H., Baltensperger, U., Brenguier, J.-L., Facchini, M., Hansson, H.-C., Hov, o., O’Dowd, C., Pöschl, U., Wiedensohler, A., Boers, R., Boucher, O., de Leeuw, G., Denier van der Gon, H., Feichter, J., Krejci, R., Laj, P., Lihavainen, H., Lohmann, U., McFiggans, G., Mentel, T., Pilinis, C., Riipinen, I., Schulz, M., Stohl, A., Swietlicki, E., Vignati, E., Alves, C., Amann, M., Ammann, M., Arabas, S., Artaxo, P., Baars, H., Beddows, D., Bergström, R., Beukes, J., Bilde, M., Burkhart, J., Canonaco, F., Clegg, S., Coe, H., Crumeyrolle, S., D’Anna, B., Decesari, S., Gilardoni, S., Fischer, M., Fjaeraa, A., Fountoukis, C., George, C., Gomes, L., Halloran, P., Hamburger, T., Harrison, R., Herrmann, H., Hoffmann, T., Hoose, C., Hu, M., Hyvärinen, A., Hõrrak, U., Iinuma, Y., Iversen, T., Josipovic, M., Kanakidou, M., Kiendler-Scharr, A., Kirkevåg, A., Kiss, G., Klimont, Z., Kolmonen, P., Komppula, M., Kristjánsson, J.-E., Laakso, L., Laaksonen, A., Labonnote, L., Lanz, V., Lehtinen, K., Rizzo, L., Makkonen, R., Manninen, H., McMeeking, G., Merikanto, J., Minikin, A., Mirme, S., Morgan, W., Nemitz, E., O’Donnell, D., Panwar, T. S., Pawlowska, H., Petzold, A., Pienaar, J., Pio, C., Plass-Duelmer, C., Prévôt, A., Pryor, S., Reddington, C., Roberts, G., Rosenfeld, D., Schwarz, J., Seland, o., Sellegri, K., Shen, X., Shiraiwa, M., Siebert, H., Sierau, B., Simpson, D., Sun, J., Topping, D., Tunved, P., Vaattovaara, P., Vakkari, V., Veefkind, J., Visschedijk, A., Vuollekoski, H., Vuolo, R., Wehner, B., Wildt, J., Woodward, S., Worsnop, D., van Zadelhoff, G.-J., Zardini, A., Zhang, K., van Zyl, P., Kerminen, V.-M., Carslaw, K., and Pandis, S.: General overview: European Integrated project on Aerosol Cloud Climate and Air Quality interactions (EUCAARI) integrating aerosol research from nano to global scales, Atmos. Chem. Phys., 11, 13 061-13 143, https://doi.org/10.5194/acp-11-13061$2011,2011$.

Kumar, P., Zavala-Reyes, J., Tomson, M., and Kalaiarasan, G.: Understanding the effects of roadside hedges on the horizontal and vertical distributions of air pollutants in street canyons, Environ. int., 158, https://doi.org/10.1016/j.envint.2021.106883, 2022.

Kurppa, M., Roldin, P., Strömberg, J., Balling, A., Karttunen, S., Kuuluvainen, H., Niemi, J. V., Pirjola, L., Rönkkö, T., Timonen, H., Hellsten, A., and Järvi, L.: Sensitivity of spatial aerosol particle distributions to the boundary conditions in the PALM model system 6.0, Geosci. Mod. Dev., 13, 5663-5685, https://doi.org/10.5194/gmd-13-5663-2020, 2020.

Kuuluvainen, H., Karjalainen, P., Saukko, E., Ovaska, T., Sirviö, K., Honkanen, M., Olin, M., Niemi, S., Keskinen, J., and Rökkö, T.: Nonvolatile ultrafine particles observed to form trimodal size distributions in non-road diesel engine exhaust, Aerosol Sc. and Tech., 54, 1345-1358, https://doi.org/10.1080/02786826.2020.1783432, 2020.

Merikanto, J., Napari, I., Vehkamäki, H., Anttila, T., and Kulmala, M.: New parameterization of sulfuric acid-ammonia-water ternary nucleation rates at tropospheric conditions, J. Geophys. Res., 112, https://doi.org/10.1029/2006JD007977, 2007.

Napari, I., Noppel, M., Vehkamaki, H., and Kulmala, M.: Parametrization of ternary nucleation rates for $\mathrm{H}_{2} \mathrm{SO}_{4}-\mathrm{NH}_{3}-\mathrm{H}_{2} \mathrm{O}$ vapors., J. Geophys. Res., 107 (D19), https://doi.org/10.1029/2002JD002132, 2002. 
Oberdörster, G., Oberdörster, E., and Oberdörster, J.: Nanotoxicology: An emerging discipline evolving from studies of ultrafine particles., Environmental Health Perspectives, 113, 823-839, 2005.

Okuljar, M., Kuuluvainen, H., Kontkanen, J., Garmash, O., Olin, M., Niemi, J., Timonen, H., Kangasluoma, J., Tham, Y., Baalbaki, R., Sipilä, M., Salo, L., Lintusaari, H., Portin, H., Teinilä, K., Aurela, M., Dal Maso, M., Rönkkö, T., Petäjä, T., and Paasonen, P.: Measurement report: The influence of traffic and new particle formation on the size distribution of 1-800 nm particles in Helsinki - a street canyon and an urban background station comparison, Atmos. Chem. Phys., 21, 9931-9953, https://doi.org/10.5194/acp-21-9931-2021, 2021.

Olin, M., Patoulias, D., Kuuluvainen, H., Niemi, J., Rönkkö, T., Pandis, S., Riipinen, I., , and Dal Maso, M.: Contribution of traffic-originated nanoparticle emissions to regional and local aerosol levels., Atmos. Chem. Phys. Discuss., in review, https://doi.org/10.5194/acp-2021466, 2021.

Panopoulou, A., Liakakou, E., Sauvage, S., Gros, V., Locoge, N., Stavroulas, I., Bonsang, B., Gerasopoulos, E., and Mihalopoulos, N.: Yearlong measurements of monoterpenes and isoprene in a Mediterranean city (Athens): Natural vs anthropogenic origin, Atmos. Environ., 243, 117 803, https://doi.org/10.1016/j.atmosenv.2020.117803, 2020.

Pascal, M., Corso, M., Chanel, O., Declercq, C., Badaloni, C., Cesaroni, G., Henschel, S., Meister, K., Haluza, D., Martin-Olmedo, P., and Medina, S.: Assessing the public health impacts of urban air pollution in 25 European cities: Results of the Aphekom project, Science of The Total Environment, 449, 390-400, https://doi.org/10.1016/j.scitotenv.2013.01.077, 2013.

Patoulias, D. and Pandis, S.: Simulation of the effects of low volatility organic compounds on aerosol number concentrations in Europe, Atmos. Chem. Phys. Discuss., p. in review, https://doi.org/10.5194/acp-2021-655, 2021.

Patoulias, D., Fountoukis, C., Riipinen, I., Asmi, A., Kulmala, M., and Pandis, S.: Simulation of the size-composition distribution of atmospheric nanoparticles over Europe, Atmos. Chem. Phys., 18, 13 639-13 654, https://doi.org/10.5194/acp-18-13639-2018, 2018.

Pikridas, M., Sciare, J., Freutel, F., Crumeyrolle, S., von der Weiden-Reinmüller, S.-L., Borbon, A., Schwarzenboeck, A., Merkel, M., Crippa, M., Kostenidou, E., Psichoudaki, M., Hildebrandt, L., Engelhart, G. J., Petäjä, T., Prévôt, A. S. H., Drewnick, F., Baltensperger, U., Wiedensohler, A., Kulmala, M., Beekmann, M., and Pandis, S. N.: In situ formation and spatial variability of particle number concentration in a European megacity, Atmos. Chem. Phys., 15, 10 219-10237, https://doi.org/10.5194/acp-15-10219-2015, 2015.

Riccobono, F., Schobesberger, S., Scott, C., Dommen, J., Ortega, I., Rondo, L., Almeida, J., Amorim, A., Bianchi, F., Breitenlechner, M., David, A., Downard, A., Dunne, E., Duplissy, J., Ehrhart, S., Flagan, R., Franchin, A., Hansel, A., Junninen, H., Kajos, M., Keskinen, H., Kupc, A., Kürten, A., Kvashin, A., Laaksonen, A., Lehtipalo, K., Makhmutov, V., Mathot, S., Nieminen, T., Onnela, A., Petäjä, T., Praplan, A., Santos, F., Schallhart, S., Seinfeld, J., Sipilä, M., Spracklen, D., Stozhkov, Y., Stratmann, F., Tomé, A., Tsagkogeorgas, G., Vaattovaara, P., Viisanen, Y., Vrtala, A., Wagner, P., Weingartner, E., Wex, H., Wimmer, D., Carslaw, K., Curtius, J., Donahue, N., Kirkby, J., Kulmala, M., Worsnop, D., and Baltensperger, U.: Oxidation products of biogenic emissions contribute to nucleation of atmospheric particles., Science, 16, 717-721, https://doi.org/10.1126/science.1243527, 2014.

Rivas, I., Beddows, D. C., Amato, F., Green, D. C., Järvi, L., Hueglin, C., Reche, C., Timonen, H., Fuller, G. W., Niemi, J. V., Pérez, N., Aurela, M., Hopke, P. K., Alastuey, A., Kulmala, M., Harrison, R. M., Querol, X., and Kelly, F. J.: Source apportionment of particle number size distribution in urban background and traffic stations in four European cities, Environ. Int., 135, 105345 , https://doi.org/10.1016/j.envint.2019.105345, 2020.

Rivas, I., Vicens, L., Basagaña, X., Tobias, A., Katsouyanni, K., Walton, H., Hüglin, C., Alastuey, A., Kulmala, M., Harrison, R., Pekkanen, J., Querol, X., Sunyer, J., and Kelly, F.: Associations between sources of particle number and mortality in four European cities., Environ. Int., 155, 106 662, https://doi.org/10.1016/j.envint.2021.106662, 2021. 
Royer, P., Chazette, P., Sartelet, K., Zhang, Q., Beekmann, M., and Raut, J.-C.: Comparison of lidar-derived PM10 with regional modeling and ground-based observations in the frame of MEGAPOLI experiment, Atmos. Chem. Phys., 11, 10 705-10 726, https://doi.org/10.5194/acp11-10705-2011, 2011.

Sartelet, K., Hayami, H., Albriet, B., and Sportisse, B.: Development and preliminary validation of a modal aerosol model for tropospheric chemistry: MAM, Aerosol Sc. and Tech., 40, 118-127, https://doi.org/10.1080/02786820500485948, 2006.

Sartelet, K., Debry, E., Fahey, K., Roustan, Y., Tombette, M., and Sportisse, B.: Simulation of aerosols and gas-phase species over Europe with the Polyphemus system. Part I: model-to-data comparison for 2001., Atmos. Environ., 41, 6116-6131, https://doi.org/10.1016/j.atmosenv.2007.04.024, 2007.

Sartelet, K., Couvidat, F., Wang, Z., Flageul, C., and Kim, Y.: SSH-Aerosol v1.1: A Modular Box Model to Simulate the Evolution of Primary and Secondary Aerosols., Atmosphere, 11, 525, https://doi.org/10.3390/atmos11050525, 2020.

Schraufnagel, D. E.: The health effects of ultrafine particles, Exp. Mol. Med., 52, 311-317, https://doi.org/10.1038/s12276-020-0403-3, 2020.

Sihto, S.-L., Kulmala, M., Kerminen, V.-M., Dal Maso, M., Petäjä, T., Riipinen, I., Korhonen, H., Arnold, F., Janson, R., Boy, M., Laaksonen, A., and Lehtinen, K.: Atmospheric sulphuric acid and aerosol formation: implications from atmospheric measurements for nucleation and early growth mechanisms, Atmos. Chem. Phys., 6, 4079-4091, https://doi.org/10.5194/acp-6-4079-2006, 2006.

Sulo, J., Sarnela, N., Kontkanen, J., Ahonen, L., Paasonen, P., Laurila, T., Jokinen, T., Kangasluoma, J., Junninen, H., Sipilä, M., Petäjä, T., Kulmala, M., and Lehtipalo, K.: Long-term measurement of sub-3 nm particles and their precursor gases in the boreal forest., Atmos. Chem. Phys., 21, 695-715, https://doi.org/10.5194/acp-21-695-2021, 2021.

Tröstl, J., Chuang, W., Gordon, H., Heinritzi, M., Yan, C., Molteni, U., Ahlm, L., Bianchi, F., Wagner, R., Simon, M., Lehtipalo, K., Williamson, C., Craven, J., Duplissy, J., Adamov, A., Almeida, J., Bernhammer, A.-K. Breitenlechner, M., Brilke, S., Dias, A., Ehrhart, S., Flagan, R., Franchin, A., Fuchs, C., Guida, R., Gysel, M., Hansel, A., Hoyle, C., Jokinen, T., Junninen, H., Kangasluoma, J., Keskinen, H., Kim, J., Krapf, M., Kürten, A., Laaksonen, A., Lawler, M., Leiminger, M., Mathot, S., Möhler, O., Nieminen, T., Onnela, A., Petäjä, T., Piel, F., Miettinen, P., Rissanen, M., Rondo, L., Sarnela, N., Schobesberger, S., Sengupta, K., Sipilä, M., Smith, J., Steiner, G., Tomè, A., Virtanen, A., Wagner, A., Weingartner, E., Wimmer, D., Winkler, P., Ye, P., Carslaw, K., Curtius, J., Dommen, J., Kirkby, J., Kulmala, M., Riipinen, I., Worsnop, D., Donahue, N., and Baltensperger, U.: The role of low-volatility organic compounds in initial particle growth in the atmosphere, Nature, 533, 527-531, https://doi.org/10.1038/nature18271, 2016.

Vehkamäki, H., Kulmala, M., Napari, I., Lehtinen, K., Timmreck, C., Noppel, M., and Laaksonen, A.: An improved parameterization for sulfuric acid-water nucleation rates for tropospheric and stratospheric conditions, J. Geophys. Res., 107, 4622, https://doi.org/10.1029/2002JD002184, 2002.

Win-Shwe, T.-T. and Fujimaki, H.: Nanoparticles and Neurotoxicity, Int. J. Mol. Sci., 12, 6267-6280, https://doi.org/10.3390/ijms12096267, 2011.

$\mathrm{Xu}$, G., Wang, J., and Qiao, X.: Numerical study on evolution of ultrafine particles emitted from vehicle exhaust with multi-dynamical behaviors., Atmos. Environ., 24, 117 916, https://doi.org/10.1016/j.atmosenv.2020.117916, 2021.

Ye, Q., Li, H. Z., Gu, P., Robinson, E. S., Apte, J. S., Sullivan, R. C., Robinson, A. L., Donahue, N. M., and Presto, A. A.: Moving beyond Fine Particle Mass: High-Spatial Resolution Exposure to Source-Resolved Atmospheric Particle Number and Chemical Mixing State, Environmental Health Perspectives, 128, 017 009, https://doi.org/10.1289/EHP5311, 2020. 
https://doi.org/10.5194/acp-2022-22

Preprint. Discussion started: 17 January 2022

(C) Author(s) 2022. CC BY 4.0 License.

(c) (1)

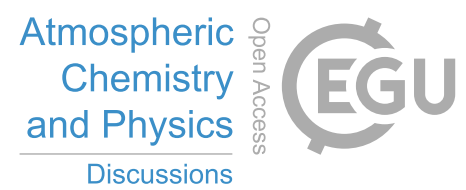

Yu, X., Venecek, M., Kumar, A., Hu, J., Tanrikulu, S., Soon, S.-T., Tran, C., Fairley, D., and Kleeman, M.: Regional sources of airborne ultrafine particle number and mass concentrations in California, Atmos. Chem. Phys., 19, 14 677-14 702, https://doi.org/10.5194/acp-1914677-2019, 2019.

Zhang, Y., Liu, P., Liu, X.-H., Jacobson, M., McMurry, P., Yu, F., Yu, S., and Schere, K.: A comparative study of nucleation parameterizations:

5 2. Three-dimensional model applications and evaluation, J. Geophys. Res., 115, https://doi.org/10.1029/2010JD014151, 2010a.

Zhang, Y., McMurry, P., Yu, F., and Jacobson, M.: A comparative study of nucleation parameterizations: 1. Examination and evaluation of the formulations, J. Geophys. Res., 115, https://doi.org/10.1029/2010JD014150, 2010b.

Zhu, J. and Penner, J.: Global Modeling of Secondary Organic Aerosol With Organic Nucleation, J. Geophys. Res.: Atm., 124, 8260-8286, https://doi.org/10.1029/2019JD030414, 2019. 